\title{
Dr. Etheridge Returns To Calgary
}

Recently, Dr. D. E. Etheridge, Forest Biologist with the Forest Pathology Laboratory, Calgary, completed his doctorate thesis after two years at the Imperial College of Science and Technology, London. In London, he was engaged in studies dealing with a problem concerning decay resistance in slowgrown and fast-grown subalpine spruce. This problem arose from field investigations on the ecology of decays on the East Slope Region and the present intention is to continue this work with other species in the province.

\section{New Timber Sale Provisions}

Reforestation of cut over timber lands, by the levy of $\$ 1.00$ per thousand FBM on the amount of timber measured or sold each month, will be placed to the credit of the successful bidder on a timber sale. The block of timber located in the Vicary Creek area of the Eastern Rockies forest Conservation area, involves approximately $17,378,000 \mathrm{FBM}$ of spruce, $7,528,000 \mathrm{FBM}$ of pine and $1,794,000$ FBM of balsam fir.

In addition to the regular dues, the extra levy will constitute a reforestation fund to be available for reforestation by planting if, after five years of an area being logged, seedlings to the amount of one thousand per acre have not been established.

The cost of planting shall be charged to the Reforestation Fund, and any credit in the fund after 5 years of the last timber cutting shall be refunded.

Conditions of the sale specify scattering or lopping of brush or windrowing and burning in accordance with the licensee plan to obtain forest regeneration.

All abandoned skid roads and trails must be blocked off and seeded to grass, or other action to prevent erosion, under advisement with the Forest Officer.

A strip along the Forestry Trunk Road will be left intact with its tree cover.

A protected strip 150 feet wide back from the high water mark of Vicary Creek or any other watercourse will be left.

This is one of a number of blocks in the area which will successively be offered for sale on cutting terms designed to either establish regeneration on the logged-over areas, or failing that to bring about the planting of "fail" areas.

Contributed by W. H. McCardell

\section{Forest Zoology in Alberta}

The Forest Insect and Disease Survey has for some time recognized the importance of conducting the survey in the Northwest Territories as well as in Alberta. Each year more and more survey work is being done in the northern area. Although much of the area is reported to have been burned over, there are still excellent stands of timber along the Liard, Slave, and Mackenzie Rivers. One mill is operating within 100 miles of the Arctic Coast. There is a large spruce budworm outbreak along the Mackenzie River.

Populations of the lodgepole needle miner in the Rocky Mountain National Parks have decreased until at the present time no outbreak exists. Papers now in press, of particular interest to foresters, assess the damage done to lodgepole 